8 Ojegov S. İ. Slovär ruskogo iazyka: Ok. 53000 slov /—M., Oniks, Mir i Obrazovanie, 2007. - 1200 s. kitap.

МРНТИ 16.21.51

\author{
Ordabayev Ch., ${ }^{1}$ Aldashev $N .,{ }^{2}$ Nabidullin A. ${ }^{3}$ \\ ${ }^{1,3}$ Abai Kazakh National University, \\ Almaty, Kazakhstan \\ ${ }^{2}$ K.Zhubanov Aktobe Regional University, \\ Aktobe, Kazakhstan
}

\title{
PECULIARITIES OF MOBILE APPLICATION USAGE IN TEACHING ENGLISH FOR UNIVERSITY STUDENTS
}

\begin{abstract}
Mobile technologies are increasingly being introduced into our lives, becoming ubiquitous, acquiring more and more advanced opportunities for social interaction and connection to the Internet. Technologies like these can have a big impact on the entire educational process. Learning will increasingly move away from the audience and enter the student's personal space, both real and virtual, and become more personal with elements of cooperation. Finding a new way of using mobile technologies to integrate them into learning as an extension of daily life will be considered a success. A fairly wide range and variety of existing mobile learning resources allow you to choose applications in accordance with the individual needs, interests and level of the student's language training. This article is dedicated to finding peculiarities of mobile application usage in teaching English for university students.
\end{abstract}

Keywords: mobile educational, mobile applications, language learning software, online education, Internet technologies

$$
\begin{gathered}
\text { Ордабаев Ч.К., }{ }^{1} \text { Алдашев Н.М., }{ }^{2} \text { Набидуллин А.С. }{ }^{3} \\
{ }^{1,3} \text { Абай атындавы Қазақ ұлттық педагогикалық университеті, } \\
\text { Алматы, Қазақстан } \\
{ }^{2} \text { Қ.Жұбанов атындавы Ақтөбе өңірлік университеті, } \\
\text { Ақтөбе, Қазақстан }
\end{gathered}
$$

\section{УНИВЕРСИТЕТ СТУДЕНТТЕРІН АҒЫЛШЫН ТІЛІН ОҚЫТУДА МОБИЛЬДІ ҚОСЫМШАЛАРДЫ ҚОЛДАНУ ЕРЕКШЕЛІКТЕРІ}

\section{Аннотаиия}

Мобильді технологиялар біздің өмірімізге барған сайын кеңінен енгізіліп, әлеуметтік өзара әрекеттесу мен оқытудың жетілдірілген мүмкіндіктеріне ие бола отырып, кеңінен таралуда. Мұндай технологиялар бүкіл оку процесіне үлкен әсер етуі мүмкін. Оқыту аудиториядан алшақтап, студенттің жеке кеңістігіне нақты да, виртуалды да енеді және ынтымақтастық элементтерімен жеке болады. Бұл аспект студенттің күнделікті өмірінің жалғасы ретінде оқуды интеграциялау үшін мобильді қосымшаларды қолданудың жаңа әдісін іздеуді қажет етеді. Қолданыстағы мобильді оқыту ресурстарының кең спектрі мен әртүрлілігі студенттердің жеке қажеттіліктеріне, қызығушылықтарына және тілдік дайындық деңгейіне сәйкес қосымшаларды таңдауға мүмкіндік береді. Мақала жоғары оқу орындарының студенттеріне ағылшын тілін оқытуда мобильді қосымшаларды қолдану ерекшеліктерін анықтауға арналған.

Түйін сөздер: мобильді оқыту, мобильді қосымшалар, тілдерді үйренуге арналған бағдарламалық қамтамасыз ету, онлайн-білім беру, интернет-технологиялар 


\author{
Ордабаев Ч.К., ${ }^{1}$ Алдашев Н.М., ${ }^{2}$ Набидуллин А.С. ${ }^{3}$ \\ ${ }^{1,3}$ Казахский национальный университет имени Абая, \\ Алматы, Казахстан \\ ${ }^{2}$ Актюбинский региональный университет имени К.Жубанова, \\ Актобе, Казахстан
}

\title{
ОСОБЕННОСТИ ИСПОЛЬЗОВАНИЯ МОБИЛЬНЫХ ПРИЛОЖЕНИЙ В ОБУЧЕНИИ АНГЛИЙСКОМУ ЯЗЫКУ СТУДЕНТОВ УНИВЕРСИТЕТОВ
}

\begin{abstract}
Аннотаичя
Мобильные технологии все чаще внедряются в нашу жизнь, становятся повсеместными, приобретая все более совершенные возможности для социального взаимодействия и обучения. Подобные технологии могут иметь большое влияние на весь образовательный процесс. Обучение будет все больше отдаляться от аудитории и входить в личное пространство учащегося, как реальное, так и виртуальное, и становиться более личным с элементами сотрудничества. В данном аспекте необходим поиск нового способа использования мобильных приложений для их интеграции в обучение в качестве продолжения повседневной жизни студента. Достаточно широкий спектр и разнообразие существующих мобильных обучающих ресурсов позволяет выбирать приложения в соответствии с индивидуальными потребностями, интересами и уровнем языковой подготовки студента. Статья посвящена выявлению особенностей использования мобильных приложений при обучении английскому языку студентов вузов.
\end{abstract}

Ключевые слова: мобильное обучение, мобильные приложения, программное обеспечение для изучения языков, онлайн-образование, интернет-технологии

Introduction. Currently, mobile technologies are developing so rapidly that they have become firmly established in our lives and no one can imagine themselves without a computer and a smartphone. This is reflected not only in everyday life, but also in all spheres of human's activity, including education.

Mobile learning began to develop in the last century and the prerequisites for this were laid in the 70s of the XX century, when Alan Kay proposed the idea of "book sizecomputers " for educational purposes. In the 90s, with the advent of pocket personal computers, the development and evaluation of mobile learning for students began, and the first educational projects for a mobile environment appeared. Fundamental research in the field of mobile learning by foreign scientists appears: T. Anderson, M. Sharles, M. Alli, D. Attevel, M.Ragus, D. Traxler. The emergence and formation of the mobile learning system is just beginning in Kazakhstan.

Mobile learning refers to e-learning through using mobile devices, regardless of time and place, using special software on a pedagogical basis of an interdisciplinary and modular approach [1].

There are many different types of technology that can be classified as mobile. They can be divided into:

1. Portable and personal - mobile phones, tablets, laptops, digital devices.

2. Stationary and public - electronic boards, lingua-phone equipment, equipment for video conferencing [2].

Mobile technologies are increasingly being introduced into our lives, becoming ubiquitous, acquiring more and more advanced opportunities for social interaction and connection to the Internet. Technologies like these can have a big impact on the entire educational process. Learning will increasingly move away from the audience and enter the student's personal space, both real and virtual, and become more personal with elements of cooperation. Finding a new way of using mobile technologies to integrate them into learning as an extension of daily life will be considered a success.

Not so long ago, the most exciting thing we could do on a mobile phone is to download and install a ringtone. Currently, users of the iOS and Android operating systems have a choice of hundreds of thousands of programs and applications. Mobile learning is not a new concept, but new devices with advanced capabilities have been the impetus for the growth of the level of interest, including among those studying foreign languages. Various programs began to appear for studying English, French, Japanese and other languages. The programs were designed for learning vocabulary with listening to audio recordings, practicing verb forms, providing an opportunity to communicate with native speakers in forums and discuss 
various topics. Also, various applications have become popular, which made it possible to exchange information online.

Research Materials and Methods. People use and will continue to use computers and laptops, but with the rapid growth of mobile devices, the way they are used is changing. As personal devices, smartphones are ideal for one-to-one informal teaching. The user independently determines which applications to use and how to use them. In turn, teachers of foreign languages should only encourage and promote student autonomy, as well as provide opportunities for combining classroom and extracurricular learning. But it must be remembered that smartphones are still quite an expensive device that not everyone can afford. And this fact cannot be ignored by teachers.

The power and small size of tablets and mobile devices allow you to learn a language virtually anywhere. Of course, there are applications, the use of which will be difficult due to the insufficient language competence of the student, but this is natural. Nowadays, all such applications are aimed at helping and guiding the student in his desire to learn the language [3].

For mobile learning to be successful, educators and technology developers must consider the following factors:

1. Content. The information contained in the application must match the interests of the students.

2. Mobility. It is very important that the device is small and lightweight. This means you can take it with you wherever you go. Students should be able to join the learning process outside of the classroom at a time that suits them, and not necessarily on schedule.

3. Education over the course of study time. To implement this factor, tools are needed that effectively organize the educational process.

4. Informality. In this case, students can use certain technologies with even more enthusiasm.

5. Ownership. Since any student wants to own and control their personal device, this factor remains important for the successful implementation of mobile learning [4].

In our opinion, training in the use of applications for mobile electronic devices is currently particularly relevant. At present, students, with all their education in the field of digital technologies, it seems to us, are not sufficiently familiar with the variety of offered software products. The teacher's task is to help the student choose the necessary and suitable products that can maximize the learning of the language, and thereby individualize the learning process. It is necessary to streamline the use of these devices by students and teach them how to use mobile devices for learning, which will optimize this process.

Currently, mobile device users have access to a huge number of applications for learning foreign languages, primarily English. Moreover, today there are mobile applications and programs focused on different aspects of teaching a foreign language.

For example, students, performing translation of a text on a specific topic, can turn to electronic dictionaries. Applications for mobile electronic devices have several advantages over their printed counterparts. Firstly, they provide quick access to information. Secondly, the vocabulary base in mobile dictionaries is usually more relevant than the printed versions. Thirdly, the use of mobile devices in the classroom and for independent work will help increase the motivation of students to learn a foreign language.

It should be noted that proper work with the electronic dictionary requires instruction from the teacher and the development of students' skills in working with information available on reference sites and reference applications. Also, the teacher's recommendation in choosing a particular resource is of great importance.

First of all, it is important to teach students to work with such monolingual explanatory dictionaries as "Merriam Webster Dictionary" and "Dictionary.com", which, in addition to the actual description of the lexical meaning, contain examples of the use of lexical units and, thus, provide information about words, phrases and idiomatic expressions within the context. In addition to transcription, these dictionaries also contain audio recording of the pronunciation of words. In the category of monolingual dictionaries, The Free Dictionary by Farlex, Inc deserves attention, as this application allows you to simultaneously search in a number of dictionaries and encyclopedias, as well as specialized terminology dictionaries for various industries, for example, such explanatory dictionaries of legal terms as "Free Law Dictionary" and "Nolo's Plain English Law Dictionary".

Of the currently presented bilingual dictionaries, the system for translators "Multitran" can be distinguished. But even when using bilingual dictionaries, students are far from always able to extract the necessary information from a dictionary entry, for example, often the most frequent meaning is used for translation, without taking into account the rest. The use of this application can be recommended for 
advanced learners, since this dictionary contains a large number of meanings of words that are not always sufficiently systematized and will be redundant at the initial stage of learning.

Mobile translation apps like Language Translator and Google Translate allow you to translate words, phrases, sentences using Google's online translation service. It is important to explain to students that translation applications only provide a translation of a word or expression, which is not always adequate.

Next, we would like to focus on applications that are designed to develop lexical skills and expand the vocabulary of students. Many of these electronic applications are designed for self-study of foreign languages and are built on a game basis.

The My Word Book application, available on the British Council website, is designed as an interactive notebook for English learners. The vocabulary in the application is presented in the form of sets of interactive flashcards, organized both in an arbitrary order and in the form of thematic groups, distributed over three levels of difficulty. Each flashcard is provided with a definition and usage example from the Cambridge University Press dictionary, translation, fields for notes, audio example, image. The "Practice" heading contains five types of tasks, after completing which the user can move a word to the list of learned vocabulary. The application was developed within the framework of the British Council training programs based on sources from Cambridge University Press, which is a reliable recommendation for its use [5].

Research result. The English with Words app is designed to work on expanding your vocabulary through fun activities in a playful way. "Words" helps to activate the memorization of new words, to train their spelling and listening comprehension. A feature of this application is that each of the eight proposed modes is aimed at practicing specific skills in the use of lexical units. During the lesson, students are encouraged to perform several exercises of different types, for example, memorizing flashcards to train memory, choosing the correct audio translation, participating in problematic mini-games.

"Easy ten" app is designed to improve your vocabulary at any level of English proficiency. The principle of operation is based on an individualized approach to the needs of the user, in particular, this application allows you to personally select words for memorization, excluding the vocabulary already familiar to the user. The words marked for learning are available in a special player that reproduces the pronunciation in English and Russian. In accordance with the established learning schedule, the application offers the user from 10 to 20 new words every day, as well as four types of tests for each word, based on different types of information perception. Interestingly, the word examples are taken from Twitter. The developers also offer daily exercise cycles to review material learned in previous sessions. To assess their progress in learning a foreign language, the user can compare their results with those of other subscribers using the rating calculated by the application.

Free «Полиглот» application. English Words contains a basic vocabulary, lists of irregular verbs, and numerous thematic vocabulary groups. Two modes of operation are available in the application: EnglishRussian dictionary, supplemented with transcription, voiced words and contexts of use, as well as training exercises, which consist in choosing one of the proposed word options to fill the gap in the sentence. All contexts are voiced and translated into Russian. The program contains separate interactive and game components, for example, the statistics of the user's success is kept, cards are periodically offered for repeating the material covered, a point reward system is installed, it is possible to create individual word lists.

The Memrise application is very popular among users - a free multifunctional application for memorizing various information. There are hundreds of courses on the official website, most of which are free. Meme cards are proposed as a mnemonic technique, which are designed to facilitate memorization of new words. The main type of work with this sentence is switching between numerous voiced vocabulary cards, which alternates with simple tasks for multiple choice [6].

Sections for the development of vocabulary skills are also included in many other applications, for example Johnny Grammar's Word Challenge, Learning English for BBC, Puzzle English and many others), and are also a necessary element of the so-called universal mobile applications for language learning, which will be discussed below.

In our opinion, many applications for replenishing vocabulary can be used, first of all, for independent work of students, for activating and developing lexical skills within the framework of the topics studied, for self-examination. At the same time, it should be noted that not all applications have high-quality language content, various types of tasks and do not fully use the technical capabilities that modern mobile devices are endowed with. 
Conclusion. During our research, we were also interested in professionally oriented applications for learning English for special purposes, in particular legal English. Unfortunately, we have to admit that developers pay very little attention to the creation of such applications, and there are no free applications at all. Nevertheless, we got acquainted with the International Legal English application, the subscription to which is quite affordable. The application is intended for students who are preparing for the international legal English exam ILEC (International Legal English Certificate Exam), during which the skills of lawyers using English in the professional field are tested. The appendix includes about 400 of the most common legal terms necessary both for exam preparation and for solving daily professional problems. All vocabulary is divided into groups by areas of law, for example, "Legal Terms", "Contract", "Company Law", "Employment Law", "Competition Law", "Real Property", "Environmental Law", "Intellectual Property". The application has two modes of operation: "Search" - a monolingual dictionary in which terms are presented in the form of flash cards with an audio version, definition, context of use. "Learn" - terms are grouped by areas of law or presented in an arbitrary sequence, also accompanied by examples and definitions. The main method of working with vocabulary is memorization, training exercises; no tests. The application is valuable for its professional orientation and the indisputable reliability of the source Cambridge University, therefore, of course, it can be used for independent work of students.

The review allows us to conclude that a significant number of mobile applications and programs for learning a foreign language have been developed to date, aimed at the formation and development of lexical skills in the English language. A fairly wide range and variety of existing mobile learning resources allow you to choose applications in accordance with the individual needs, interests and level of the student's language training. From our point of view, the practical application of mobile applications has great potential, since it increases the motivation and cognitive activity of students, interest in the subject, helps to individualize learning, and removes the psychological barrier when using a foreign language as a means of communication. In addition, the use of interactive technologies contributes to the development of foreign language competencies and the intensification of independent work of students.

\title{
References:
}

1 Куклев В. А. Становление системы мобильного обучения в открытом дистаниионном образовании. - Автореферат диссер. на соискание уч. степени докт. пед. наук. - Ульяновск, 2010. - 46 c. [Kuklev V. A. Stanovlenie sistemy mobilnogo obuchenia v otkrytom distansionnom obrazovanii. Avtoreferat diser. na soiskanie uch. stepeni dokt. ped. nauk. — Ülänovsk, 2010. - 46 s.]

2 Naismith L., Lonsdale P., Vavoula G., Sharples Literature review in mobile technologies and learning. - Futurelab. - 2004. - 44 p.

3 Godwin-Jones R. Mobile apps for language learning. - Language learning \& Technology. - June 2011, Vol.15, № 2. - pp.2-11.

4 Min Pun. The use of multimedia technology in English language Teaching: a global perspective // Crossing the Border: International Journal of Interdisciplinary Studies. - 2013. - Vol. 1. - № 1 .

5 Nergiz Kern. Technology-integrated English for Specific Purposes lessons: real-life language, tasks, and tools for professionals // Innovations in learning technologies for English language teaching. - 2013.

6 Титова С. В. Дидактические проблемы интеграчии мобильных приложений в учебный прочесс // Вестник ТГУ. - 2016. - № 7-8 (159-160). - C. 7-14. [Titova S. V. Didakticheskie problemy integrasii mobilnyh prilojeni v uchebnyi proses // Vestnik TGU. - 2016. - № 7-8 (159-160). - S. 7-14.]

\section{МРНТИ 16.31.02}

\author{
Райымбекова Ә.А. , ${ }^{1}$ Ешимов М.П., ${ }^{2}$ Нұртілеуова С.Р. ${ }^{3}$ \\ 1,2,3 дл-Фараби атындавы Қазақ ұлттық университеті \\ Алматы, Қазақстан
}

\section{ҚАЗАҚСТАНДА ОРЫС ТІЛІН ШЕТ ТІЛІ РЕТІНДЕ ОҚЫТУДА ОҚЫТУДЫҢ ИННОВАЦИЯЛЫҚ ТУРЛЕРІН ҚОЛДАНУ}

\author{
Аң̧датпа
}

Бұл мақалада орыс тілін шет тілі ретінде оқытудың инновациялық түрлері, өзге тілді оқыту тәжірибесінде жаңа технологияларды қолдану әдістері, жаңа мультимедиялық білім беру жүйесінің 